ppi $201502 Z U 4645$

Esta publicación cientifica en formato digital es continuidad de la revista impresa ISSN-Versión Impresa 0798-1406 / ISSN-Versión on line 2542-3185Depósito legal pp

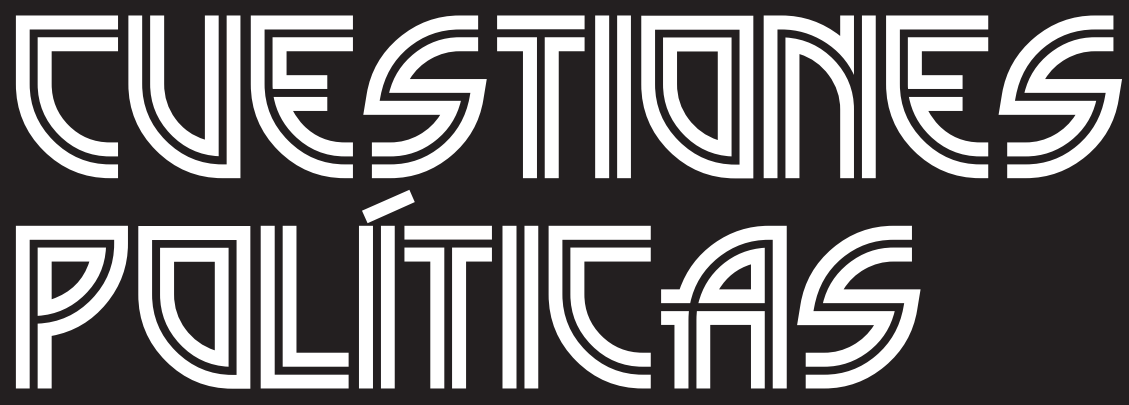

Instituto de Estudios Políticos y Derecho Público "Dr. Humberto J. La Roche' de la Facultad de Ciencias Jurídicas y Políticas de la Universidad del Zulia Maracaibo, Venezuela
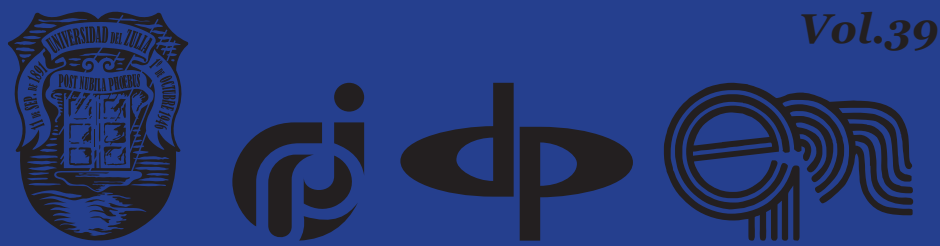


\title{
Objects of intellectual property rights created by artificial intelligence: international legal regulation
}

\author{
DOI: https://doi.org/10.46398/cuestpol.3968.32
}

\author{
Pavlo Voitovych * \\ Kateryna Bondarenko ** \\ Ruslan Ennan *** \\ Alina Havlouska **** \\ Vladyslav Shliienko $* * * * *$
}

\section{Abstract}

In modern conditions of development of public relations, the creation of objects of intellectual property rights by artificial intelligence is becoming more widespread. With this in mind, it is important to analyse the international legal experience of regulating the use of artificial intelligence as the author of intellectual property, to further borrow it for domestic laws, as well as to pay attention to problematic aspects of such regulation and make proposals to resolve inconsistencies. The study clarifies the international legal regulation of intellectual property rights created by artificial intelligence, as well as analyses the problematic issues of regulation of artificial intelligence by international law and the features of such regulation in Ukraine and presents positions on the development of artificial intelligence systems and prospects, as well as the prospects for its impact on world society.

Keywords: artificial intelligence, objects of intellectual property law, international legal regulation, robotics, Berne Convention.

* Ph.D., Ass. Professor of the Department of International and European law, National University «Odesa Law Academy ". ORCID ID: https://orcid.org/oooo-ooo2-7636-923X. Email: pvoitovich@ ukr.net

** Ph.D., Ass. Professor of the Common legal disciplines department of the National University "Odesa Maritime Academy". ORCID ID: https://orcid.org/oooo-0oo2-5799-8102. Email: bondarenkokate@ gmail.com

*** Ph. D., Ass. Professor of Department of Intellectual Property Law and Corporate Law of National University «Odesa Law Academy». ORCID ID: https://orcid.org/oooo-0002-4727-1532. Email: ennan.ruslan@gmail.com

**** Ph.D., Ass. Professor of the Department of Branch Law, Kherson State University. ORCID ID: https:// orcid.org/oooo-0002-4436-3407. Email: Lyolikalina@gmail.com

***** Ph.D. candidate of the Department of International and European law, National University "Odesa Law Academy". ORCID ID: https://orcid.org/oooo-0003-2519-0157. Email: Ladimir20152@gmail. com 
Pavlo Voitovych, Kateryna Bondarenko, Ruslan Ennan, Alina Havlovska y Vladyslav Shliienko 506

Objects of intellectual property rights created by artificial intelligence: international legal regulation

\section{Objetos de los derechos de propiedad intelectual creados por inteligencia artificial: regulación legal internacional}

\section{Resumen}

En las condiciones modernas de desarrollo exponencial de las relaciones públicas, la creación de objetos de derechos de propiedad intelectual mediante inteligencia artificial se está generalizando. Teniendo esto en cuenta, la presente investigación analiza la experiencia legal internacional de regular el uso de la inteligencia artificial como sujeto autor de la propiedad intelectual, para tomarla como referencia para las leyes de Ucrania. Además, interesó prestar atención a los aspectos problemáticos de dicha regulación, y hacer algunas propuestas para resolver sus inconsistencias. En lo metodológico se hizo uso del análisis documental. Se concluye que los derechos sobre obras creadas artificialmente pueden reconocerse por el propietario del programa informático (generalmente grandes corporaciones), sus desarrolladores o usuarios. Es decir, la cuestión principal no es el reconocimiento de la autoría de la inteligencia artificial, sino la definición legal de la persona que será propietaria de los derechos de propiedad del objeto creado por el programa con capacidades creativa autónoma (ya que el componente financiero juega un papel importante en el avance de la investigación en esta área).

Palabras clave: inteligencia artificial; objetos de derecho de propiedad intelectual; regulación legal internacional; robótica; Convenio de Berna.

\section{Introduction}

The rapid development of scientific progress has created all the conditions for the transition of technology to the category of tools, with which the creation of new intellectual property (IP) objects becomes possible, and, in some cases, to the category of tools capable of creating objects of intellectual property regulation without human intervention.

Intellectual property legislation was not prepared for such challenges, and, therefore, questions arose as to whether intellectual property objects, created by artificial intelligence (AI), can be protected by intellectual property laws. And another question is how to reform intellectual property legislation so that this kind of relations can be properly regulated, and the balance of private and public interests is maintained.

Today, the world community is discussing the objects of intellectual property rights created by artificial intelligence. Thus, the British start-up 
Jukedeck has developed artificial intelligence, which is able to write music. In 2016, the world saw the project "The Next Rembrandt" - a portrait created by a computer based on the analysis of 346 paintings by the artist.

But despite the creation of intellectual property objects by artificial intelligence, there is no proper legal regulation of such objects in domestic legislation in many countries. International norms provide guidelines governing the use of artificial intelligence in the creation of intellectual property rights and are even prepared to recognize a computer program as an artist. Therefore, given the growing number of intellectual property objects created by artificial intelligence, it is important to analyse the legislation governing this issue.

The purpose of the work is to analyse the international legal regulation of intellectual property rights created by artificial intelligence. Moreover, the object of research is the international legal regulation of intellectual property rights created by artificial intelligence. Finally, the subject of the study is the social relations that arise in the international legal regulation of intellectual property rights created by artificial intelligence.

\section{Analysis of recent research}

Legal regulation of the use of artificial intelligence is of interest to many researchers, so in order to study the doctrine on intellectual property objects created by artificial intelligence the works of the following authors were analysed: Volina (2018), Vasilieva (2019), Karchevsky (2020), Krivetsky (2020), Lavrenova and Abramovich (2019), Milonenko (2018), Militsyna (2019), Pozova (2017), Svitlichny (2016), Semkiv and Shandra (2015), Harina (2019). All the works analysed below, in one way or another, influenced the formation of this article and the argumentation of the statements made by the authors at the end of the study.

Thus, Volina (2018) in her work entitled "It is difficult to be a robot" came to the conclusion that now in most countries (for example, UK, New Zealand, India, Hong Kong) are quite skeptical about the recognition of the work as the author of the work. Besides, Vasilieva (2019) studied copyright protection for artificial intelligence. Thus, as a result of the study, she concluded that the author of works (given the general world practice), created by artificial intelligence is still a man, not a program. Moreover, Karchevsky (2020) drew attention to the main problems of legal regulation of the responsibility of artificial intelligence. He focused on a promising problem related to the emergence of the rights and obligations of robots. Also, the issue of "mixed justice" ("justice of artificial intelligence") was studied, which will solve the issue of threat to humans from artificial intelligence. Further, Krivetsky (2020) analyzed the problems of legal regulation of artificial intelligence in Ukraine. The scholar raised the question of the need for the legislator to 
Pavlo Voitovych, Kateryna Bondarenko, Ruslan Ennan, Alina Havlovska y Vladyslav Shliienko Objects of intellectual property rights created by artificial intelligence: international legal

determine the path of development of the legal framework for regulating issues related to the use of artificial intelligence: whether to recognize it as a subject that has rights and responsibilities or not

In addition, Lavrenova and Abramovich (2019) in their work asked an important question: "Are the object of intellectual property rights works created exclusively by artificial intelligence without human intervention?" And according to the results of their research of international experience (legislation, doctrine, and judicial practice), the authors ware favoured to conclude that works created by artificial intelligence are not the object of intellectual property rights.

In the study Milonenko (2018), the prospects of recognizing artificial intelligence as a subject of international law are analyzed. The researcher identifies several approaches to defining the range of subjects of international law and notes that until the middle of the twentieth century there was a "classical" concept, according to which only states were subjects of international law, and the modern doctrine of international law expands the composition of the subjects of international law, gives a detailed division. Besides, the author notes that at the moment it is advisable to recognize artificial intelligence systems as special subjects of international law because the level of interaction of intelligent machines with humans already needs regulation.

Militsyna (2019) compared the legal regulation of objects created with the help of artificial intelligence and artificial intelligence directly in Ukraine and the United States. Thus, the researcher pointed out that the question of the legal personality of artificial intelligence is on the agenda and that there are theories that insist that artificial intelligence already has manifestations of cognitive processes, so it has a consciousness that is similar to humans. Also, the researcher analyses the views of various scientists and notes that some of them believe that if you compare artificial intelligence with legal entities, artificial intelligence should also acquire legal personality. However, such theories have been sharply criticized and cannot be called dominant in the United States, as objects created with artificial intelligence and artificial intelligence directly remain unguarded in the United States. In conclusion, the author assumes that in the United States today, the author and the ability to create are identified with the man. This, in turn, is a reason to deny protection to objects created with artificial intelligence and artificial intelligence directly. Exceptions are cases where artificial intelligence remains a means. In this case, the author will be the person who used this technology. Given the existing proposals for improving copyright for such objects, we can say that the dominant trend is to maintain the anthropocentrism of copyright.

Finally, Pozova (2017) clarified the prospects of legal regulation of artificial intelligence under EU law. Thus, the author found that although 
European Parliament resolutions are not legally binding and do not enshrine any rights or obligations but are a kind of beacons that show those areas that require legislative regulation at the European level. Union, and determining the prospects for such regulation. The researcher also emphasized that the introduction of legal regulation of relations in the field of robotics in connection with the creation, circulation, use of robots is necessary, and the development of certain European legal standards for robotics and artificial intelligence will promote the development of the industry and ensure respect for human rights in the formation of new social relations with the participation of autonomous devices.

Thus, the analysis of the above literature shows that the study of artificial intelligence is a topical issue among scholars, but a comprehensive study of international legal regulation of intellectual property rights created by artificial intelligence has not been conducted. Therefore, there is an urgent need to conduct research on the international legal regulation of intellectual property rights created by artificial intelligence with the aim to create a proposition for the improvement of domestic legislation.

\section{Methodology}

The authors used different methods to study the international legal regulation of intellectual property objects created by artificial intelligence, such as the historical method; analytical method; method of analysis of legal documents, articles, and monographs; methods of classification; method of generalization; comparison; synthesis; as well as modelling.

Thus, firstly, the historical method allowed us to analyse the evolution of the international legislation governing the use of artificial intelligence and intellectual property in different time periods and in different historical conditions.

Secondly, the analytical method made it possible to consider in detail the regulations of both international and national legislation on AI and IP and to identify their main ideas, provisions, guidelines for development.

What is more, the method of analysis of legal documents, articles, and monographs was used in the study of legislation and scientific works of scholars on the research topic. Thanks to this method, it was possible to comprehensively study the work of many scholars and identify the main principles of regulation of artificial intelligence in different countries (legal systems).

The generalization method allowed to combine the general provisions on the use of artificial intelligence and regulation of intellectual property objects (taking into account the existing international legal acts regulating these issues). For example, the provisions of the Berne Convention (1886) 
have generalized the provisions on the guidelines governing the creation of intellectual property objects; the Civil Code of Ukraine (2003) allowed to analyse and generalize how the objects of intellectual property rights created by artificial intelligence in Ukraine are regulated; the provisions of the legislation of various European countries made it possible to understand the approach to regulating the creation of objects by artificial intelligence in Europe.

The method of comparison allowed us to compare the regulation of intellectual property objects created by artificial intelligence in different countries. This helped for a comprehensive study, namely: to see the differences in legal regulation, to identify legal gaps, and to investigate how the problematic issues can be resolved in different countries.

Furthermore, the method of synthesis was used to study certain regulations governing relations in the field of intellectual property and the use of artificial intelligence in the creation of works, programs, compositions, etc. in order to form coherent vectors of development and improve such regulations.

Finally, the use of the modelling method allowed to model how to further develop relations in the field of legal regulation of intellectual property objects created by artificial intelligence and how it is necessary to reform the domestic legislation so that it can be in harmony with international law and meets the requirements of time and social development.

When writing the article, much attention was paid to international and domestic law. The following legislation on the topic was analysed:

- Berne Convention for the Protection of Literary and Artistic Works, approved by the World Intellectual Property Organization (1886).

- European Parliament resolution of 16 February 2017 with recommendations to the Commission on Civil Law Rules on Robotics (2015/2103(INL).

- Directive No 2001/29/EU of the European Parliament and of the Council of 22 May 2001.

- Copyright, Designs, and Patents Act of 1988.

- The judgment of the United Nations International Court of Justice (ICJ) in the case of Nottebohm (Liechtenstein v. Guatemala) of 1955.

- Universal Copyright Convention of 1952.

- Agreement on Trade-Related Aspects of Intellectual Property Rights (TRIPS Agreement) of 1995.

- $\quad$ The Constitution of Ukraine of 1996. 
- Civil Code of Ukraine of 2003.

- Law of Ukraine "On Ukraine's accession to the Berne Convention for the Protection of Literary and Artistic Works" (1995), and;

- Law of Ukraine “On Copyright and Related Rights” (1994).

\section{Presentation of key research findings}

\subsection{Provisions of international legislation on the regulation of the creation and use of the objects of IP created by AI}

Thus, first of all, it is necessary to analyse the provisions of international legal regulation of the creation, use of intellectual property rights, and the use of artificial intelligence products. Thus, concerning international legal regulation, the guidelines of intellectual property law are contained in the Berne Convention (1886). The Berne Convention became the first multilateral international copyright treaty. It establishes uniform minimum rights for intellectual property. The principles of the Berne Convention form the basis of the Universal Copyright Convention (1952), reaffirmed and extended in the Agreement on Trade-Related Aspects of Intellectual Property Rights (TRIPS Agreement) (1995). According to the Berne Convention and Universal Copyright Convention, the term "author" can be understood as both individuals and legal entities under the national legislation of the participating countries.

The development of robotics and artificial intelligence and related legal and ethical issues led to the adoption by the European Parliament of the Resolution of February 16, 2017 with proposals to the European Commission on civil law on robotics. The Resolution emphasizes the need to address the issue of civil liability for damage caused by robots at the European level to ensure equal efficiency, transparency, and consistency in addressing this issue in the EU member states. Besides, the resolution is based on the fact that in the long run, the capabilities of artificial intelligence may exceed human capabilities, so they will be able to enter into contractual relationships, choose contractors, discuss the terms of contracts, enter into and execute them. What is more, the Resolution also focuses on safety and liability issues related to the operation of robots. In particular, it is envisaged that drivers of autonomous vehicles should be able to take control of the car as quickly as possible when needed. Thus, at this stage of the study, it would be logical to say that works created exclusively by artificial intelligence can be objects of intellectual property rights.

European Parliament Resolution 2015/2013 (INL) of 16 February 2017, which includes the Charter on Robotics, stipulates that robotics is subject to the current system of legal regulation of intellectual property issues, to intellectual property rights - a neutral approach from the standpoint of 
Pavlo Voitovych, Kateryna Bondarenko, Ruslan Ennan, Alina Havlovska y Vladyslav Shliienko Objects of intellectual property rights created by artificial intelligence: international legal

technology. In particular, legal protection of objects created by artificial intelligence systems should be provided taking into account the neutral legal personality, because behind the artificial intelligence systems, first of all, there is a person.

In April 2019, the European Commission published a Directive on an ethical approach to the development of artificial intelligence (draft) for study by industry. The main provisions of the document are that artificial intelligence should be created to support human subjectivity, and artificial intelligence systems and the results of their activities should be "humancentred, aimed entirely at serving humanity and the common good, to help improve the conditions of human existence and freedom".

In May 2019, the Organization for Economic Cooperation and Development, which unites 36 economically developed countries, together with six countries (and then in June 2019, the Ministers of Economy of the G20 countries) defined the principles of dealing with artificial intelligence. It was based on two principles:

- in order to increase trust in technology and realize its full potential, it is necessary for a person to be at the centre of the use of artificial intelligence.

- $\quad$ systems must be stable, secure, and reliable throughout the period of their use, and must not carry any unacceptable risks.

From a legal point of view, the recommendations of the Organization are not binding. However, they are designed to form a unified approach to the interpretation of the criteria for the protection of the performance of artificial intelligence in different jurisdictions.

Also noteworthy is the 1955 decision of the United Nations International Court of Justice in Nottebohm (Liechtenstein v. Guatemala). This decision was motivated by Part 1 of Article 15 of the Universal Declaration of Human Rights of 1948, which clearly states that "everyone has the right to a nationality". Citizenship is recognized as an element not only of the exclusive legal personality of individuals but also of artificial intelligence systems. In view of the above, the question arises about the mandatory international delictual capacity of artificial intelligence systems.

It is also important to note the interpretation of EU Directive 2001/29/ EU on certain aspects of copyright. It is stated that a computer program must be protected if it is original in the sense that it is the author's intellectual work. This is justified by the fact that any literary and artistic works, or any other intellectual works must be protected by copyright. This applies, in particular, to databases.

On September 27, 2019, a discussion organized by WIPO on the impact of artificial intelligence on the intellectual property took place. The discussion 
considered various issues related to the impact of artificial intelligence on almost all processes related to the implementation of copyright. The influence of Artificial Intelligence on patent law was also discussed, but we are interested in the position on authorship. As a result of the discussion, the participants came to the conclusion that the legislative process and changes in legislation take a long time. Therefore, if necessary, the issue of recognizing artificial intelligence as the author of the work may be left to the discretion of the court. Moreover, participants agreed that with the development of information technology, it is becoming increasingly difficult to determine who created a work: human or artificial intelligence (Conversation on Intellectual Property (IP) and Artificial Intelligence (AI), 2019).

Additionally, the attention should be paid to the program called "Bot Dylan" (2020), which has created a large number of musical works for which no authorship has yet been established. The program used generated a piece of music so that it is impossible to recognize who was the original author. Moreover, this project also does not have copyright protection.

Thus, even at the supranational level, there are different positions on the issue of recognizing artificial intelligence as the author of a work that is protected by intellectual property rights. If we put the supranational assets, listed above, in chronological order, we can reverse the tendency to gradually expand the potential expansion of possible rights attached to artificial intelligence.

In most cases, supranational regulations are of a recommendatory nature. That is why there is a need to address the national level of regulation of this issue in different countries. Why the next section of the article will be devoted?

\subsection{Regulation of the objects of intellectual property rights created by artificial intelligence in foreign countries (national level)}

Let's briefly consider how the objects of intellectual property rights created with the help of artificial intelligence in foreign countries (at the national level) are regulated.

Thus, in the United States, the Copyright Office will register an original copyrighted work if it was created by human. This position is in line with the law, which states that copyright protects only the object of intellectual work, the foundations of which are the creative abilities of the mind. This position is also supported by Australian legislators.

Meanwhile, the US legal doctrine also has positions on the recognition of authorship by artificial intelligence. Hence, it is believed that artificial 
Pavlo Voitovych, Kateryna Bondarenko, Ruslan Ennan, Alina Havlovska y Vladyslav Shliienko Objects of intellectual property rights created by artificial intelligence: international legal

intelligence already has manifestations of cognitive processes, so it has a consciousness that is similar to humans. Comparing artificial intelligence with legal entities, some researchers believe that it is logical that artificial intelligence should also acquire legal personality (Yanisky-Ravid, 2017). In addition, artificial intelligence can create works under contract as a worker (work for hire). In this case, the author of the work will be the employer (Hristov, 2017).

In Japan, it was decided to start developing regulations to protect copyright in creative products generated by artificial intelligence. This step is taken to support companies working to create and implement innovations.

In the United Kingdom, the Copyright, Design and Patent Act (1988) states that in the case of a computer-generated literary, dramatic, musical, or artistic work, the author will be the person through whom the activities necessary to create the work are carried out. The same provisions are contained in the legislation of Hong Kong, South Africa, and New Zealand. The position that the originality of work (according to the legislation of most countries) is the result of the expression of the author's personality opposes the position on the recognition of artificial intelligence as the author of the work. This criterion cannot yet be applied to artificial intelligence. Most copyright laws require the awareness of the creation. A machine does not have that conscience (Conversation on Intellectual Property (IP) and Artificial Intelligence (AI), 2019).

In India, there is a basis for recognizing artificial intelligence as the author of a work. If we consider the case law, the position of the Indian courts is that creativity must be respected wherever it comes from, so artificial intelligence has the right to acknowledge authorship. Even taking into account the outdated norms of the law, the courts interpret these norms broadly and skilfully apply them to information technology. Indian courts note whether the creation of a work by artificial intelligence took place under human supervision, or whether artificial intelligence created it without human intervention. This is a key factor. Meanwhile, if we turn to the legal framework and adhere only to the law, then currently the author of the work can only be a person.

Thus, the analysis of international legal regulation of the objects of intellectual property rights created by artificial intelligence shows that despite the short period of creation of this objects by works and other means of non-human origin, states (including international organizations legislate the regulation of such objects) taking into account the specifics of such objects and the legal traditions of the states themselves. 


\subsection{Domestic (Ukrainian) regulation of intellectual property issues}

Article 41 of the Constitution of Ukraine (1996) stipulates that everyone has the right to own, use, and dispose of the results of their intellectual and creative activity.

According to Art. 420 of the Civil Code of Ukraine (2003), the objects of intellectual property rights include literary and artistic works; computer programs; data compilation (database); implementation; phonograms, videograms, broadcasts (programs) of broadcasting organizations; scientific discoveries; inventions, utility models, industrial designs; layout (topography) of integrated circuits; innovation proposals; plant varieties, animal breeds; commercial (brand) names, trademarks (signs for goods and services), geographical indications; trade secrets.

Objects of copyright in accordance with the Law of Ukraine "On Copyright and Related Rights" (1994: article5) are works in the field of science, literature and art, namely: literary works of fiction, journalism, scientific, technical or other nature (books, brochures, articles, etc.); speeches, lectures, and other oral works; computer programs; databases; musical works with text and without; dramatic, musical-dramatic works, pantomimes, choreographic, and other works created for stage performance and their staging; audiovisual works; works of fine art; works of architecture, urban planning and landscape art; photographic works, including works made in a manner similar to photography; works of applied art, including works of decorative weaving, ceramics, carving, foundry, art glass, jewellery, etc.; illustrations, maps, plans, drawings, sketches, plastic works relating to geography, geology, topography, engineering, architecture and other areas of activity; stage adaptations of the works, and arrangements of folklore suitable for stage performance; derivative works; collections of works, collections of folklore, encyclopaedias and anthologies, collections of ordinary data, other compiled works, provided that they are the result of creative work on the selection, coordination or arrangement of content without infringing copyright on the works included in them as part; texts of translations for dubbing, sounding, subtitling in Ukrainian and other languages of foreign audio-visual works; other works.

The subjects of intellectual property rights are the creator (creators) of the object of intellectual property rights (author, performer, inventor, etc.) and other persons who own personal non-property and (or) property intellectual property rights (Civil Code of Ukraine, 2003: article 318).

That is, in Ukrainian law, the subject of intellectual property rights is the creator and other persons. It is stated that the creator is exclusively an individual. Legal entities under civil law cannot be creators, but they can become the primary subjects of intellectual property rights by law. Thus, 
Pavlo Voitovych, Kateryna Bondarenko, Ruslan Ennan, Alina Havlovska y Vladyslav Shliienko 516

Objects of intellectual property rights created by artificial intelligence: international legal

artificial intelligence under Ukrainian law cannot be a subject of intellectual property rights, and there is no legislative regulation on the issue of intellectual property rights created by artificial intelligence.

\section{Conclusions}

As a result of the study of international legal regulation of objects of intellectual property rights created by artificial intelligence, we came to the following conclusions:

1. In the international community, the majority holds that rights to artificially created works can recognize by the owner of the computer program (usually large corporations), its developers, or users. That is, the main issue is not the recognition of authorship of artificial intelligence, but the legal definition of the person who will own the property rights to the object created by the program (as the financial component plays an important role in advancing further research in this area).

2. In the case of defending the position on which artificial intelligence (robot) can be recognized as a subject of intellectual property rights, it should be borne in mind that artificial intelligence operates according to an algorithm and often generates new works as a result of processing and analysis of existing ones. In this case, to provide a work of legal protection, it is necessary to establish the criteria of originality in the newly created work.

3. At present, there are developments in the regulation of international law of objects of intellectual property rights created by artificial intelligence. However, such developments are not applied by states due to conflicts and non-recognition by many foreign states of the legal personality of artificial intelligence, which leads to inconsistencies and lack of a unified approach to the recognition or non-recognition of artificial intelligence as a legal entity.

4. Ukrainian legislation does not set the legal basis for the use of works created without human participation. Thus, the legislation of our state does not yet give grounds to recognize the authorship of intellectual property by artificial intelligence. However, given the discussion in the international arena of the status of robots, including the possibility of recognizing them as "electronic persons", this situation may change in the near future.

Therefore, the research topic requires further research, namely a detailed analysis of bills and theoretical developments and doctrines on consolidating artificial intelligence at the legislative level and giving it legal personality, as well as litigation on the recognition of artificial intelligence as a subject of intellectual property rights. 


\section{Bibliographic References}

BOT DYLAN. 2020. Available online. In: http://www.bobdylan.com/. Consultation date: 11/02/2020.

EUROPEAN COMMISSION. 2020. Shaping Europe's digital future. Available online. In: https://ec.europa.eu/digital-single-market/en. Consultation date: $10 / 04 / 2020$.

EUROPEAN UNION. 2001. Directive No 2001/29/EU. Available online. In: https://zakon.rada.gov.ua/laws/show/984_005-01\#Text. Consultation date: $10 / 02 / 2020$.

EUROPEAN UNION. 2017. Resolution with recommendations to the Commission on Civil Law Rules on Robotics (2015/2103(INL)). Available online. In: https://robopravo.ru/riezoliutsiia_ies. Consultation date: 08/08/2019.

HARINA, Mariia. 2019. "On the issue of regulating the legal status of artificial intelligence in international law and Ukrainian law" In: Young scientist. Vol.5(69), pp. 500-503. Available online. In: http://nbuv.gov.ua/UJRN/ molv_2019_5\%282\%29_54. Consultation date: 10/02/2020.

HRISTOV, Mykola. 2017. "Artificial Intelligence and the Copyright Dilemma" In: The Journal of the Franklin Pierce Center for Intellectual Property. Vol. 57, No.1, pp. 12-45.

KARCHEVSKY, Mykola. 2020. The main problems of legal regulation of socialization of artificial intelligence, in IT law: problems and prospects of development in Ukraine. Available online. In: http://aphd.ua/ publication-369/. Consultation date: 10/05/2020.

KRIVETSKY, Oleksandr. 2020. On the problem of legal regulation of artificial intelligence. Center for Social Communications Research. Available online. In: http://nbuviap.gov.ua/index.php?option=com content\&view $=$ article $\& i d=3728:$ do - problemi-pravovogoregulyuvannya-shtuchnogo-intelektu\&catid $=8 \&$ Itemid $=350$. Consultation date: 10/05/2020.

LAVRENOVA, Nataliia; ABRAMOVICH, Nataliia. 2019. "Are the works created by artificial intelligence an object of intellectual property rights?” In: Lawyer \& Law. Vol. 17 (1). Available online. In: https://www.legalalliance. com.ua/publikacii/ci-e-obektom-prava-intelektualnoi-vlasnosti-tvoristvoreni-stucnim-intelektom/. Consultation date: 08/09/2019.

LAW OF UKRAINE. 1994. On Copyright and Related Rights: Law. Available online. In: https://zakon.rada.gov.ua/laws/show/3792-12\#Text. Consultation date: 21/10/2019. 
Pavlo Voitovych, Kateryna Bondarenko, Ruslan Ennan, Alina Havlovska y Vladyslav Shliienko 518 Objects of intellectual property rights created by artificial intelligence: international legal regulation

LAW OF UKRAINE. 1995. On Ukraine's accession to the Berne Convention for the Protection of Literary and Artistic Works: Law. Available online. In: https://zakon.rada.gov.ua/laws/show/189/95\%Do\%B2\%D1\%80\#Text. Consultation date: 01/02/2020.

MILITSYNA, Kateryna. 2019. "Objects created with the help of artificial intelligence and artificial intelligence directly, and US copyright" In: Entrepreneurship, economy and law. Vol. 5, No. 1, pp. 343-346. Available online. In: http://pgp-journal.kiev.ua/archive/2019/5/65.pdf. Consultation date: $01 / 11 / 2019$.

MILONENKO, Yurii. 2018. "The prospect of recognizing artificial intelligence as a subject of international law" In: Young Scientist. Vol. 11(63), pp. 125 - 127. Available online. In: http://molodyvcheny.in.ua/files/ journal/2018/11/31.pdf. Consultation date: 08/08/2019.

ORGANIZATION FOR ECONOMIC COOPERATION AND DEVELOPMENT. 2019. Development Co-operation Report. Available online. In: https:// www.oecd.org/dac/development-cooperation-report/. Consultation date: 01/02/2020.

POZOVA, Diana. 2017. "Prospects for legal regulation of artificial intelligence under EU law" In: Journal of Civilization. Vol. 1 (1), pp. 116-120. Available online. In: http://nbuv.gov.ua/UJRN/Chac_2017_27_24. Consultation date: 08/02/2020.

SEMKIV, Vitalii; SHANDRA, Roman. 2015. Intellectual property. Ukraine: Lviv. Available online. In: https://law.lnu.edu.ua/wp-content/upload s/2017/01/\%Do\%86\%Do\%BD\%D1\%82\%Do\%B5\%Do\%BB\%Do\%B5 \%Do\%BA\%D1\%82\%D1\%83\%Do\%Bo\%Do\%BB\%D1\%8C\%Do\%BD\% Do\%Bo-\%Do\%B2\%Do\%BB\%Do\%Bo\%D1\%81\%Do\%BD\%D1\%96\%D 1\%81\%D1\%82\%D1\%8C.\%Do\%9F\%D1\%96\%Do\%B4\%D1\%80\%D1\%8 3\%D1\%87\%Do\%BD\%Do\%B8\%Do\%BA.2015.pdf. Consultation date: 01/08/2020.

SVITLICHNY, Oleksandr. 2016. Intellectual property law. Kiev. Available online. In: https://www.businesslaw.org.ua/wp-content/Pidruchnyk_ Pravo_intel_vlasnosti.pdf. Consultation date: 26/02/2020.

UKRAINE. 1996. The Constitution of Ukraine. Available online. In: https:// zakon.rada.gov.ua/laws/show/254\%Do\%BA/96-\%Do\%B2\%D1\%80. Consultation date: 01/11/2019.

UKRAINE. 2003. Civil Code of Ukraine. Available online. In: https://zakon. rada.gov.ua/laws/show/435-15\#Text. Consultation date: 01/02/2020.

UNITED KINGDOM. 1988. Copyright, Designs, and Patents Act. Available online. In: https://www.legislation.gov.uk/ukpga/1988/48/pdfs/ ukpga_19880048_en.pdf. Consultation date: 21/10/2019. 
UNITED NATIONS. 1948. Universal Declaration of Human Rights. Available online. In: https://www.un.org/en/universal-declaration-humanrights/. Consultation date: 26/09/2019.

UNITED NATIONS. 1952. Educational, Scientific and Cultural Organization, Universal Copyright Convention. Available online. In: http://portal. unesco.org/en/ev.php-URL_ID=15381\&URL_DO=DO_TOPIC\&URL_ SECTION=201.html. Consultation date: 21/10/2019.

UNITED NATIONS. INTERNATIONAL COURT OF JUSTICE (ICJ). 1955. Nottebohm (Liechtenstein v. Guatemala): judgment. Available online. In: https://www.icj-cij.org/en/case/18/judgments. Consultation date: 29/04/2020.

VASILIEVA, Daryna. 2019. "Copyright protection for AI: a game ahead" In: Legal newspaper online. Vol. 45-46(1), pp. 699-700. Available online. In: https://yur-gazeta.com/publications/practice/informaciynepravo-telekomunikaciyi/zahist-avtorskih-prav-dlya-ai-gra-naviperedzhennya.html. Consultation date: 26/04/2020.

VOLINA, Tamara. 2018. "It is difficult to be a robot" In: Law and Business. Vol. 28(1), pp. 1-14. Available online. In: https://zib.com.ua/ua/print/133716avtorom_tvoru_shtuchnogo_intelektu_mozhe_buti_viznana_lishe_. html. Consultation date: 26/04/2020.

WORLD INTELLECTUAL PROPERTY ORGANIZATION. 1886. Berne Convention for the Protection of Literary and Artistic Works. Available online. In: https://zakon.rada.gov.ua/laws/show/995_051\#Text. Consultation date: 17/02/2020.

WORLD INTELLECTUAL PROPERTY ORGANIZATION. 2019. Conversation on Intellectual Property (IP) and Artificial Intelligence (AI). Available online. In: https://www.wipo.int/meetings/en/details.jsp?meeting $\mathrm{id}=51767$. Consultation date: $17 / 02 / 2020$.

WORLD TRADE ORGANIZATION. 1995. Agreement on Trade-Related Aspects of Intellectual Property Rights (TRIPS Agreement). Available online. In: https://www.wto.org/english/docs_e/legal_e/27-trips.pdf. Consultation date: $26 / 02 / 2020$.

YANISKY-RAVID,Shlomit.2017."GeneratingRembrandt:ArtificialIntelligence, Copyright, and Accountability in the 3A Era - the Human-like Authors are Already Here - a New Model” In: Michigan State Law Review, Vol. 1(1), pp. 684-689. Available online. In: https://digitalcommons.law. msu.edu/cgi/viewcontent.cgi?article $=1199 \&$ context $=$ lr. Consultation date: $17 / 08 / 2019$. 

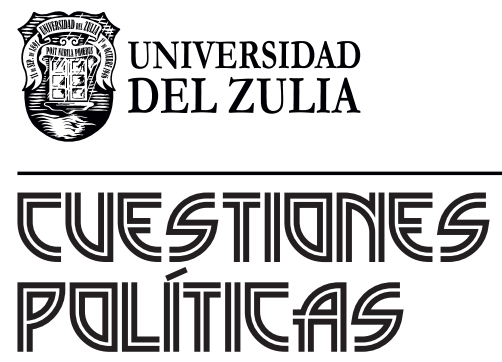

Vol.39 No 68

Esta revista fue editada en formato digital y publicada en enero de 2021, por el Fondo Editorial Serbiluz, Universidad del Zulia. Maracaibo-Venezuela 